\title{
The Effects of Legal Measures to Empower Supervisory Directors: Evidence from a Financial Distress Perspective
}

\author{
Bernard P.A. Santen ${ }^{1} \&$ Auke de Bos ${ }^{2}$ \\ ${ }^{1}$ Leiden Law School, Leiden University, Leiden, the Netherlands \\ ${ }^{2}$ Financial Accounting, Erasmus School of Law, Erasmus University Rotterdam, Rotterdam, the Netherlands \\ Correspondence: Bernard P.A. Santen, senior researcher, Leiden Law School, Leiden University, Leiden, the \\ Netherlands. E-mail: b.p.a.santen@law.leidenuniv.nl
}

Received: December 15, 2014

Accepted: January 14, $2015 \quad$ Online Published: January 29, 2015

doi:10.5430/jms.v6n1p45

URL: http://dx.doi.org/10.5430/jms.v6n1p45

\begin{abstract}
A great number of studies have been conducted over the past 20 odd years in search of the Holy Grail of corporate governance: the relationship between the corporate governance structure of a company and its financial performance. These studies predominantly hypothesize that 'better' corporate governance generates better corporate performance. The analysis is 'upward-performance' directed. This paper stresses that the 'downward performance' issue i.e. how does the company handle arising serious financial difficulties, is equally important, since it affects the sustainability of the company. A governance structure that facilitates the company to discover, analyse and solve its problems in a timely manner will improve the chances to avoid or survive serious financial difficulties. Our analysis shows that measures to strengthen the position of supervisory directors, to require a minimum number and a minimum availability are statistically significantly more often found in the control group of companies than in our financially distressed group. As for measures to ascertain independence and diversity of supervisors, our results suggest that these provisions have opposite effects. Control companies have less diverse and less independent supervisory boards than financially distressed companies.
\end{abstract}

Keywords: financial distress, governance structure, NEDs, supervisory directors

\section{Introduction}

Over the past 20 odd years numerous studies have been conducted in search of the Holy Grail of corporate governance: the relationship between the corporate governance structure of a company and its financial performance. A meta-analysis by Dalton, Daily, Ellstrand and Johnson (1998) of research addressing the relationships between board composition, board leadership structure, and company financial performance provided little evidence of systematic governance structure/financial performance relationships. Ten years later, Romano, Bhagat and Bolton (2008) concluded again that the empirical literature focusing on individual governance mechanisms has not consistently identified a relationship between governance and performance measured in terms of e.g. Tobin's Q, return on assets, ratio of sales to assets, or market adjusted stock price returns.

The underlying studies predominantly hypothesize that 'better' corporate governance e.g. separation of the CEO and Chairman position, or a majority of independent non-executive directors (NEDs) on the board, generates better corporate performance. The analysis is 'upward-performance' directed. However, the corporate governance structure of a company may not only influence its 'upward performance', but also its 'downward performance' i.e. how the company handles arising serious financial difficulties. Better downward performance will result in better chances on survival in times of near financial distress. If the governance structure facilitates the company to discover, analyse and solve its problems in a timely manner, it will improve the chances to avoid or survive serious financial difficulties which may otherwise result in financial distress. Although this effect is mostly overlooked, it is of an existential nature for the company. Once a company becomes financially distressed it may finally go bankrupt. By then, usually it will cease to exist and shareholders, employees and creditors will suffer losses in terms of wealth and money, reputation and happiness. And even when a turnaround of the company succeeds, the costs to shareholders and creditors will be large. Santen (2011) calculated the creditor loss due to company bankruptcies in the Netherlands at $0.4 \%$ of GDP annually over the period $1992-2008$.

Simply avoiding financial distress may very well be the primary task of the corporate governance structure of a company. This paper focuses on governance by supervisory directors on the two-tier board as well as by NEDs on 
the one-tier board near financial distress. It is multidisciplinary since it applies legal as well as economic insights. Figure 1 summarizes the research question of this paper.

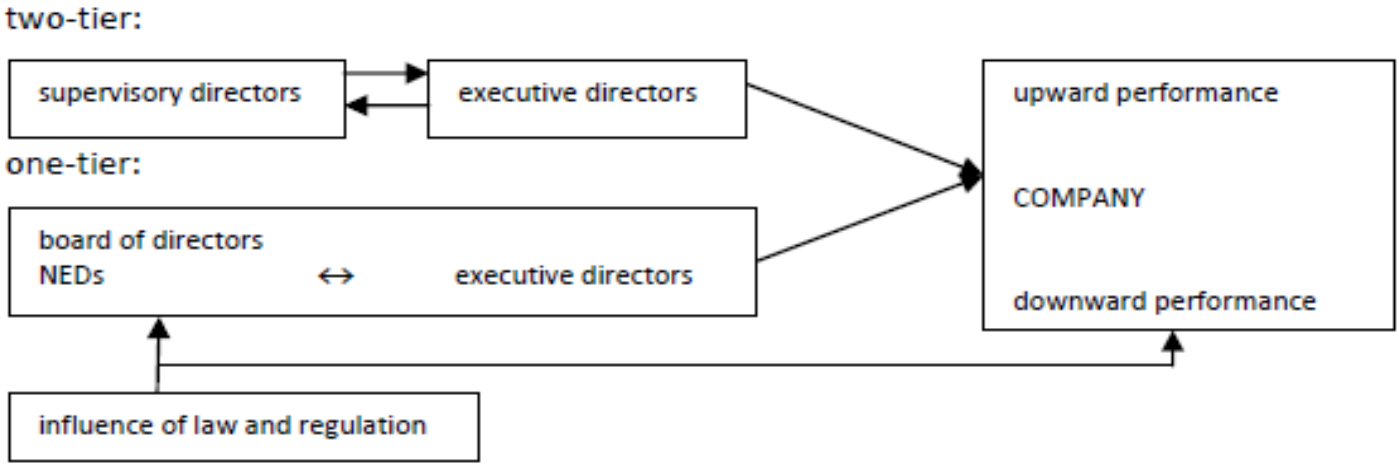

Figure 1. The outline of the research question of this paper

As Figure 1 shows, the research question of this paper is whether law and regulation directed to the position of supervisory directors and NEDs, improves the company's capacity to handle upcoming serious financial difficulties (i.e. its 'downward performance'). Section 2 starts with a conceptual description of the supervision structure of companies from an economic as well as from a legal perspective. It describes a number of legal and regulatory measures taken to enhance governance by supervisory directors. Subsequently, section 3 elaborates on the hypotheses to be tested. Section 4 describes the data of the 201 Dutch listed companies that were subject of our research. Section 5 gives the statistical analysis of the data. Then, in section 6 we confront the results from the statistical analysis with the legal and regulatory measures taken. It answers the question whether these measures from a financial distress perspective, were rightly targeted. Section 7 concludes. This paper is unique since (a) it is the first to study the corporate governance structure in a two-tier board system from a financial distress perspective and (b) it confronts research on the effectiveness of governance by the supervisory board (SB) with recent and older legal and regulatory measures expected to enhance this governance.

\section{Supervision Structure: Economic Theory and the Law}

\subsection{An Introduction to Economic Theory on Supervision Structure}

Since Jensen and Meckling (1976) we know that executive directors (agents) and shareholders (principals) have a different utility function, and that monitoring is one of the solutions to avoid shareholder expropriation by managers. In economic terms, a proper monitoring structure recognizes a separation between decision management and decision control (Fama and Jensen, 1983). Decision management contains the initiation and the implementation phase. Business ideas have to be gathered, tested, formulated and presented. This is the initiation phase of a decision. The actual implementation follows next. Both are executive responsibilities. However, before implementation a proper review of the proposal is necessary in order to avoid e.g. blind spots, tunnel vision or outright mistakes. This review resorts under decision control, i.e. a monitoring mechanism should check out the proposal thoroughly and ratify it, before the implementation phase will be entered into. Decision control is a non-executive responsibility. During respectively after implementation, non-executives should monitor whether things go according to plan, and finally evaluate whether the goals set earlier have been met. This separation of decision management and decision control as developed by Fama and Jensen (1983) can be applied on all levels in the organization. In fact it is the basis of all corporate governance theory.

Subsequently, corporate governance researchers focussed amongst others on the legal position, the quantity and the quality of monitors. If monitors are expected to function properly, they should have tools. They need power based on the law and the articles e.g. rights to be informed, to appoint and to dismiss executives, and to co-decide on certain issues of key-importance to the company. Moreover, their number should not be too small, in order to avoid autocratic behaviour (Argenti, 1986A), nor too large, in order to be effective (Lipton and Lorsch, 1992). Concerning quality, the independence of NEDs of the company and of its executive directors (EDs) should be guarded as mainstream theory says, and the majority, to some even: the supermajority, of the NEDs should be independent (Jensen, 1993). From independence it is a small step to substance: what does a monitor add to the company? One issue is resources. Monitors should be able to connect the company to external resources: the resource dependence theory (Pfeffer and Salancik, 1978; Hillman and Dalziel, 2003). Another issue is diversity. Monitors should reflect the societal majority of women and e.g. ethnic diversity (Carter, F. D'Souza, Simkins and Simpson, 2010). The availability of NEDs is a rather recent issue (Higgs, 2003). At present companies are required to report on the presence of NEDs at meetings and reappointments of 'overboarded' NEDs have been declined for reasons of inadequate availability. 
This paper analyses data on these issues for monitors i.e. supervisory directors, of companies in times of near financial distress.

\subsection{An Introduction to the Legal Approach on Supervision Structure}

The majority of companies do not have a separate decision control mechanism at all. In most small and medium-sized entities (SMEs) the executives initiate, ratify, implement and control all by themselves. This may be due to anything between the size of the company and autocratic leadership. That the lack of monitors or the unwillingness to communicate with them preludes difficulties, which may eventually result in financial distress, is convincingly shown by Argenti (1976), Argenti (1986A), Argenti (1986B), Skeel (2005) and Keough (2008). Creditor and investor protection lie therefore at the heart of governance measures taken by legislators and regulating agencies.

Often the legal system prescribes the mandatory establishment of a SB once the company has a certain legal form e.g. the German AG; a certain size e.g. the German GmbH if over 500 employees or the Dutch NV and BV if the 'structure regime' applies; or if it is listed (USA, UK). The Dutch 'structure regime' applies to public and private companies and cooperatives with a capital of over $€ 16$ million, a works council, and over 100 employees in the Netherlands (Note 1). However, since there are many exemptions (Note 2), for example for holding companies if the majority of its employees is employed outside the Netherlands, the structure regime does not apply to a number of large Dutch companies e.g. Unilever NV, Royal Philips Electronics NV, Randstad NV and Royal Ahold NV.

The embedment of non-executives on the company may either take the form of NEDs on the board i.e. the one-tier system (USA, UK) or that of a separate SB i.e. the two-tier system (Germany, the Netherlands). The advantage of the one-tier system is said to be the immediate and timely involvement in the decision process. NEDs are partners in the board decisions. However, by the same token, this involvement may corroborate their independence of judgement since they may be drawn into a tunnel vision. The advantage of a two-tier system being that supervisory directors form a separate board which decides without any intermingling of EDs as a separate decision control mechanism, is widely recognized (Albert, 1993; Jensen, 1993). Therefore US law as well as British law recognizes the separate position of NEDs through structures such as a special position of the Senior NED, and separate meetings of NEDs. The Netherlands shows a contrary movement since recent legislation enables the establishment of a one-tier board as of 1 January 2013.

Remarkably, provisions on the establishment of a SB or the appointment of NEDs do generally concern company forms i.e. the Plc, Ltd, AG, GmbH, NV and BV. Other legal forms for organizations, such as cooperatives (except in Germany and the Netherlands), associations, foundations or trusts, however large they may be, do often not recognize a legal rule on the establishment of a supervisory structure.

\subsection{The Legal Measures under Scrutiny}

In this paper we analyse from a financial distress perspective the effects of Dutch governance provisions on the monitoring characteristics described in section 2.1 of this paper, i.e. (1) the power of supervisory directors in the company, (2) their number, and the (3) independence, (4) diversity and (5) availability of the SB. The resource issue described in 2.1 is left aside since the data is insufficient. This section describes the Dutch provisions related to these monitoring characteristics and compares them whenever possible with relevant regulation in Germany, the UK and the USA in order to see what experiences from elsewhere could contribute to our knowledge.

The analysis starts with the establishment and the legal power of the SB. An attempt in 1971 to improve corporate governance of the Dutch NV avant la lettre, led to a legal distinction between an 'ordinary NV' and a 'structure NV', the latter to be applied either mandatory, mitigated or voluntarily. A 'structure NV' has a mandatory SB, an 'ordinary NV' may have an SB by choice. In a 'structure NV' the SB (1) appoints the EDs (Note 3), (2) it has to ratify executive board (EB) decisions listed in the law and the articles, and before 2004, when the law was changed, the SB (3) appointed the supervisory directors through co-option and (4) it adopted the annual accounts. From October 2004 onwards, the competences (3) and (4) have been assigned to the shareholders. However, during the period under investigation the SB in the 'structure NV' held all four competences.

Section 2:164 Dutch Civil Code (DCC) contains a rather extensive list of EB decisions to be ratified by the SB for the 'structure NV' (Note 4). It provides for the approval by the SB of EB-resolutions on e.g. (a) the issue and acquisition of company shares; of depositary receipts for shares; an application for admission to trading of its shares on an exchange; a proposal to reduce its issued capital; (b) the entry or termination of long-term cooperation contracts that are of a major significance for the company; the acquisition of a participating interest in the capital of another company equalling at least $25 \%$ of its equity; an investment requiring at least $25 \%$ of its equity; (c) a proposal to amend the articles, to wind up the company or to apply for bankruptcy; and (d) the termination of the employment of a considerable number of employees; or a significant change in their working conditions. The articles may extend this list. Ordinary NVs do not seldom voluntarily copy part of this legal list in their own articles. Germany has a similar concept of a SB with separate decision control tasks (Calkoen 2011). German law provides for a system, where the decision rights of the SB may stem from the law, from the articles or from a decision by the 
SB itself, that specific kinds of decisions need its approval (Note 5). Like in the Netherlands, management tasks cannot be transferred (Note 6).

However, strategy is not on the Dutch list of supervisory directors competences. While NEDs on a one-tier board have a monitoring, disciplining and strategy role (Zahra and Pearce, 1989; Blair, 1995; the UK corporate governance code (UKCGC), Main Principle A.4) supervisory directors on a two-tier board generally have no decisive powers on strategy. In the Netherlands, the Supreme Court (Hoge Raad) decided in 2007 that strategy is an EB prerogative (Note 7). The German position is identical since the German Corporate Governance Code (GCGC) states in 3.2 that the 'management board (Note 8) coordinates the enterprise's strategic approach with the supervisory board and discusses the current state of strategy implementation with the supervisory board at regular intervals.'

German and Dutch law mention a minimum number of three supervisory directors. The mandatory number of German supervisory directors may increase up to 20 according to the number of employees, if the so called Mitbestimmungsgesetz applies (Note 9). In the Netherlands the minimum of three only applies if the company is a 'structure NV' (Note 10). A number of NEDs has not been fixed in the USA or UK. However, existing regulations on the establishment and composition of the board and its committees may in effect determine a certain minimum (Duchina, Matsusakab and Ozbazb, 2010). The British Listing Rules (Note 11) require through the UKCGC that at least half of the board of a listed company should comprise independent NEDs and for smaller companies there should be at least two. In the USA, the SEC, NYSE and Nasdaq provide for e.g. a majority requirement for outside directors on the board (Note 12).

Independence is an issue in Dutch and German law (Note 13), but much more so in their governance codes. Since 2003, the Dutch Corporate Governance Code (DCGC) requires, subject to the 'comply or explain rule' formulated in the law (Note 14), in III.2.1 that all SB members, with the exception of not more than one person, shall be independent. A person is qualified independent if he, or his wife, partner or family member in the second degree has not been employed by the company in the past five years; does not receive personal benefits from the company; has not had a business relationship (consultant, counsel, banker and the like) in the year previous to the appointment; is not or does not represent a $10 \%$ shareholder; and is not an ED on a company in which an ED of the company he supervises is a supervisory director or a NED (cross-directorship) (Note 15). In Germany, the GCGC (Note 16) provides in 5.4.2 that the SB shall include what it considers an adequate number of independent members. A member is not to be considered independent in particular if he/she has personal or business relations with the company, its executive bodies, a controlling shareholder or an enterprise associated with the latter which may cause a conflict of interests. Not more than two former members of the EB shall be members of the SB and SB members shall not exercise directorships or similar positions or advisory tasks for important competitors of the company. In England, the UKCGC criteria in B.1.1. relating to independence are similar to the Dutch. However, independence is to be determined by the board. If the board determines that a director is independent notwithstanding the existence of relationships or circumstances which may appear relevant to its determination, it should state its reasons. The US Sarbanes Oxley Act and Frank Dodd Act made provisions for independence for respectively the audit committee and the compensation committee. Through SEC regulations, these provisions have been worked out in for example rule 303A.02(a) of the NYSE Listed Company Manual: "no director qualifies as 'independent' unless the board of directors affirmatively determines that the director has no material relationship with the listed company (either directly or as a partner, shareholder or officer of an organization that has a relationship with the company)." In 303A.02(b) one finds familiar criteria such as an employment or business relationship with the company.

Legal concerns on the diversity of supervisory directors or NEDs are relatively new. Since 2004 Dutch law requires a 'structure NV' to develop a profile (Note 17) for the SB. Dutch, German en UK corporate governance codes require some form of diversity or at least attention to the issue (Note 18). In 2012 the Dutch legislator has followed the example of Norway. As of 1 January 2013 the law requires at least 30\% men and at least $30 \%$ women on the EB as well as on the SB (Note 19). Other types of diversity, i.e. diversity in terms of expertise, age, ethnic origin or nationality are no specific subject of legal concern, but are supposedly part of the general 'profile' requirement. In Germany, law will require as of 2016 that $30 \%$ of supervisory directors will be female (listed companies only). And EU-law to improve the gender balance on the boards of companies is underway.

A company with supervisors in adequate number who are independent and diverse may even so feel empty handed if these supervisors are not available when needed. Availability of NEDs is an issue ever since the Higgs report (2003) in the UK. The UKCGC states under Main Principle B.3 ('Commitment') that all directors should be able to allocate sufficient time to the company to discharge their responsibilities effectively. The related code provisions explain that NEDs should undertake that they will have sufficient time to meet what is expected of them (B.3.2.). The DCGC merely notes on the availability issue under III.3.4: The number of supervisory boards of Dutch listed companies of which an individual may be a member shall be limited to such an extent that the proper performance of his duties is assured. However, it adds a maximum number of five for which purpose the chairmanship of a SB counts double. From 1 January 2013 Dutch law extends this provision to 'large' companies, either in the NV, BV or stichting (foundation) form. (Note 20) 


\section{Hypotheses}

This section develops the hypotheses on the monitoring characteristics sketched in section 2 with regard to financial distress. Section 4 describes the data and section 5 reports the results.

Since almost all listed companies have a SB, we cannot test a hypothesis on the added value of a SB. We can however formulate hypotheses on the power of supervisory directors as well as on their number, independence, diversity and availability.

\section{power of supervisory directors}

De Jong, DeJong, Mertens and Wasley (2005) hypothesize the structure regime has a negative relation with firm value and their results support this hypothesis. Van Ees, Postma and Sterken (2003) claim that the co-option feature hinders the alignment of SB and shareholder interests. However, this is exactly what Dutch law in section 2:140 DCC requires: in the performance of their duties, supervisory directors shall be guided by the interests of the company, so states the law. Although this may clearly hinder optimization of shareholder interests, one cannot reasonably suppose that this lack of alignment would have a negative effect in situations of near financial distress. The SB will look after the interests of the firm as it legally should do, and after its own interests e.g. in terms of reputational damage. The SB will undoubtedly do its utmost to avoid financial distress by means of the rights assigned to it. Since the SB is more powerful in a 'structure NV' than in an ordinary NV the first hypothesis reads:

\section{$H_{1}$ : being a 'structure $N V$ ' is negatively related to financial distress.}

number of supervisory directors

Most board-size related research is on the one-tier board and based on US data. Lipton and Lorsch (1992) argued that the size of the board may inhibit a meaningful dialogue since 'it becomes more and more difficult for directors to express their ideas and opinions in the limited time available. This contributes to the expectation (..) that directors are not supposed to voice their opinions freely and frequently.' While they opted for a board size limited to a maximum of ten, favouring eight or nine, Jensen (1993), on similar grounds advised a maximum of seven or eight. Baker and Gompers (2003) reported for 1,116 companies around their IPO a board size of six (mean and median), while the vast majority of the boards numbered between four and seven. Yermack (1996) reported for a panel of major (Forbes-500 listed) US companies a mean and median board size of twelve. It should be noted that although US companies are on average four times bigger than Dutch companies, Dutch boards i.e. EB and SB taken together, are on average two-thirds the size of US boards (Van Ees, Postma et al., 2003). It may be concluded that boards grow degressively with the size of the firm.

Research of Yermack (1996) concludes that small boards are more effective. He reports an inverse association between firm value and board size. Andres, Azofra and Lopez (2005), in a sample of 450 companies from ten countries, found a negative relationship between firm value and board size (Note 21). They concluded that the disadvantages with regard to communication, flexibility and coordination(Note 22) outweigh the potentially better manager control as a result of a larger board. Van Ees, Postma et al. (2003) reported for the Netherlands that the size of the SB has a negative impact on performance. Beiner, Drobretz, Schmid and Zimmermann (2004), however, did not find a significant relationship between board size and firm valuation. They concluded that their sample of Swiss firms with a median one-tier board size of six seemed in fact to have chosen their board size optimally: depending on and varying with the underlying environment in which they operated. Less effectiveness of larger boards on the remuneration issue has been reported (Mertens and Knop, 2010). Since most research indicates a negative influence of larger boards, we hypothesize:

\section{$\mathrm{H}_{2}$ : the number of supervisory directors is positively related to financial distress.}

\section{independence of supervisory directors}

International literature stresses the importance of non-independence of NEDs in order to do a proper supervision job (Fama and Jensen, 1983; Jensen, 1993). Consequently NEDs should not have economic ties with the company other than this supervision function and be no large shareholder, former executive or advisor. For bankrupt companies, Daily and Dalton (1994) found higher proportions of non-independent directors than for the control companies. However, Klein (1998) convincingly showed the importance of non-independent NEDs on the board. Becht, Bolton and Roëll (2005) report that the findings concerning the effects of independent NEDs are mixed (Note 23). Bhagat and Black (2002) report hints in their data that firms with more independent boards perform worse. This is confirmed in their 2008 study, which shows that board independence is negatively correlated with contemporaneous and subsequent operating performance (Bhagat and Bolton, 2008). Van Zijl (2012) performed a meta-analysis with a sample of 52,182 company year observations of 43 studies from the last decade. His results as well show a significant negative relationship between board independence and performance, measured either as ROA or Tobin's Q. Based on these recent empirical findings we hypothesize that in times of near financial distress the availability on the SB of specific, company related knowledge may well be important. So, we hypothesize:

$$
H_{3} \text { : the incidence of non-independent supervisory directors is negatively related to financial distress. }
$$




\section{diversity of supervisory directors}

Diversity could be defined as broad as diversity with respect to demographic attributes (Pelled, 1996) or as narrow as the percentage of women or minorities on the board of directors (Carter, Simkins and Simpson, 2003). Modern agency theorists favour board diversity as they believe that a greater diversity of opinions and interests on the board should keep managerial discretion within proper bounds (Francoeur, Labelle and Sinclair, 2007). A more diverse board might be a more activist board because outside directors with non-traditional characteristics could be considered the ultimate outsider (Carter, Simkins et al., 2003). In short, one could expect from theory that more resourceful NEDs are less likely to oversee managerial mistakes which could lead to financial distress, and that they will react more adequately once financial distress is at hand. However, Farrell and Hersch (2005) explain that greater gender diversity may simply be the firm's response to outside or inside pressure on the diversity issue. Furthermore, the results of Adams and Ferreira (2009) show that although female directors have a substantial and value-relevant impact on board structure, there is no evidence suggesting that a quota-based policy would improve firm performance on average.

Ruigrok, Peck and Tacheva (2007) conclude on nationality that a foreigner on the board on the one hand brings different perspectives, skills and knowledge, but on the other hand different values, norms and understanding that may influence the effectiveness of communication. Moreover, foreigners often lack know-how of the local legal and accounting system (Note 24). According to Van Veen and Elbertsen (2008) the level of nationality diversity on the board in the Netherlands is the highest in Europe. Carter, D'Souza et al. (2010) conclude that if a diverse group, whether defined by gender, ethnicity, language, religion, education, or some other dimension, is highly integrated, then any noticeable difference in the behaviour of corporate directors from that diverse group might be minimal. Although the results are mixed, theory arguably supports the following hypothesis:

\section{$\mathrm{H}_{4}$ : the diversity of the $\mathrm{SB}$ is negatively related to financial distress.}

availability of supervisory directors

Whether supervisory directors or NEDs will be available for the company if needed, will highly depend on their workload. Workload is a fiercely debated topic in resource dependence literature. Clearly, a NED may become 'overboarded' from being exposed to numerous challenges from the directorships and other jobs he occupies. He may very well be too busy to meet all the requirements attending his responsibilities properly (Harris and Shimizu, 2004). While Lipton and Lorsch (1992) argue that such NEDs have too little time to carry out their duties, Harris and Shimizu (2004) find that overboarded directors are important sources of knowledge, enhance acquisition performance and are an important complement for a board. In the analysis of Hambrick (1987) time is only a sub-factor. Some may have more time than others, but, as Harris and Shimizu (2004) observe, busy directors are busy for good reason - they are good contributors. That is why Kiel and Nicholson (2006) object to this line of research. It is conceptually the wrong level of analysis and it neglects the various systemic benefits of multiple directorships. Instead, boards and individual directors should regularly be evaluated to see if they can still carry out the roles expected of them. One wonders whether in situations of near financial distress (a) there is time to execute this evaluation, (b) if a firm can permit to lose NEDs on those grounds just at that very moment, and (c) if 'overboarded' NEDs really have the opportunity to invest the extra time needed. Intuitively one would hypothesize that in situations of near financial distress a firm is better off with non-overboarded supervisory directors:

$$
H_{5} \text { : the workload of supervisory directors is positively related to financial distress. }
$$

\section{Data}

Object of research are listed Dutch NVs that became financially distressed in the period 1993-2003. A company is considered to be financially distressed either if it went bankrupt, were granted suspension of payments or qualified for suspension of listing (group 1); or if it suffered at least three years of unintended sequential losses (group 2). The research period covers a complete economic cycle. Of all the companies listed on the Amsterdam Stock Exchange for three or more years during 1993-2003, 57 became financially distressed. Of these, 34 went bankrupt, were granted suspension of payments or qualified for suspension of listing (group 1). For two out of these 34 companies it was impossible to retrieve data. The other 23 companies of the distressed sample suffered at least three years of unintended sequential losses (group 2). A company with that record normally faces serious financial difficulties. Of these 23 cases, two companies were excluded as they did not meet the additional requirement of a three-year listing (Note 25) before the situation of distress. This requirement was formulated in order to have sufficient data. One distressed foreign company was excluded as it does not have to comply with Dutch company law. As a result the financially distressed sample consists of 32 bankrupt and 20 otherwise financially distressed companies.

This type of research mostly works with a matched-pairs control sample in order to study the differences between a financially distressed and a 'normal' non-distressed company, further referred to as a 'control' company (Zmijewski, 1984). A matched-pairs approach presupposes the availability of comparable companies in industry and size in the control sample to match with those of the distressed sample. Since the Netherlands is a relatively small country, these (listed) comparable companies are often lacking. There is no match for bankrupt companies such as Fokker 
(aviation); DAF (heavy trucks); Homburg (meat processing); Verto (ropes); Tulip (computer assembly); UPC (cable-network); KPN Quest (data storage). This makes a matching approach rather tricky if not impossible. Therefore the choice has been made to report the results based on a 'complete' control sample (Note 26). This 'complete' control sample consists of 149 companies listed for five or more years during 1993-2003. The five-year criterion is set in order to have stable and well-organized companies in the control sample. If a company merged or de-listed after two years of consecutive losses it fell out of the control sample because this merger or delisting could indicate financial distress. In the case of a merger between listed companies, either the new or the merged company could qualify for the control sample. Banks, insurance companies, investment funds, real estate funds and foreign companies were excluded from the study (Hermalin and Weisbach, 1988). Companies from the control sample were proportionally and randomly assigned over the years according to the percentage of financially distressed companies in each year.

We analyse the data of $t=-3$ and $t=-2$ before the financial distress event occurs. Data for $t=-1$ is at least for bankrupt companies generally unavailable. Since control companies will suffer financial difficulties as well without becoming financially distressed, we thus implicitly assume that the differences in the SB in $t=-3$ and $t=-2$ decisively influence the working of the SB and its impact on the EB (being both black boxes) and therewith the outcome of financial difficulties at hand (Figure 1).

The data is retrieved from the annual reports, the Chamber of Commerce (Note 27), the WMZ (Note 28) register, the Handboek voor directeuren en commissarissen (Note 29) and newspapers. The number of supervisory directors is determined at the end of the calendar year. His independence is measured according to the criteria of the DCGC, defined in 2.3 above. To determine the workload, a regular job e.g. ED, advisor, professor, Member of Parliament, lawyer or auditor, classifies as a full-time equivalent (FTE) which means it takes 1,800 hours a year. This is arbitrary since part-time jobs exist more and more. A supervisory directorship on a listed company is assumed to take 100 hours/year, and one on a private limited company 50 hours/year. A chairmanship counts double. A 200 hours/year approach for a listed NV, in line with Winter and Cools (2008) and Goodridge (2007), would probably overestimate the 1990's culture (Lipton and Lorsch, 1992). Supervisory directors may occupy directorships in foundations or associations, often of an honorary nature, which may, at least incidentally, take up a lot of a time as well. These posts have not been taken into account since the data is not complete by any means, and estimating the time involved would have been possible only with an unacceptable degree of subjectivity.

Based on the literature e.g. Ohlson (1980), Daily and Dalton (1994), Hill, Perry and Andes (1996) and Pompe and Bilderbeek (2000) four financial control variables are chosen, which relate to size, leverage, profitability and liquidity. For size this study applies LNTA, the natural logarithm of total assets (TA) in millions of $€$. CETA, the leverage variable, is the quotient of common equity (CE) and TA. Pompe and Bilderbeek (2000) show that the best measure of income is NITA, the quotient of net income (before extraordinary items; NI) and TA. As a measure of liquidity they advise CASHVV (total cash flow divided by all liabilities). Financial data is retrieved from Thomson Worldscope and, in the case of non-availability, from the annual reports. Finally, we take industry as a control variable, based on the two-digit level of the Nomenclature statistique des activités économiques dans la Communeauté Européene (NACE).

\section{Results}

Subsection 5.1 contains a statistical analysis on the relationship between the monitoring characteristics mentioned earlier, i.e. power, number, independence, diversity and availability, and financial distress. Since these results could be biased by the industry or by the long term establishment of the structured regime in a company, subsection 5.2 analyses the monitoring variables in this respect as well. Section 6 will confront these results with the law and discuss the effectiveness of the legal and regulatory measures taken.

\subsection{The Financial Distress Angle}

This subsection focusses on the differences in SB characteristics between financially distressed and other listed companies. Table 1 describes and analyses the data.

Table 1. An analysis of supervisory board related variables and financial control variables for the control sample and the financially distressed sample of listed Dutch companies from 1993 to 2003, based on panel data for $t=-2$ and $t=$ -3 before the financial distress event in the financially distressed sample occurred

\begin{tabular}{|c|c|c|c|c|c|c|c|c|c|}
\hline & \multicolumn{2}{|c|}{ control sample } & \multicolumn{6}{|c|}{ financially distressed sample } & \multirow{2}{*}{$\begin{array}{l}\text { difference } \\
\text { t-value } \mid \\
\text { (|z-value } \mid)\end{array}$} \\
\hline variable & number & $\begin{array}{l}\min \\
(\max )\end{array}$ & $\begin{array}{c}\text { mean } \\
\text { (median) }\end{array}$ & $\begin{array}{l}\text { standard } \\
\text { deviation }\end{array}$ & number & $\begin{array}{l}\min \\
(\max )\end{array}$ & $\begin{array}{c}\text { mean } \\
\text { (median) }\end{array}$ & $\begin{array}{l}\text { standard } \\
\text { deviation }\end{array}$ & \\
\hline$t=-2$ & & & & & & & & & \\
\hline STRUCTURED & 149 & & $62.42 \%$ & & 52 & & $38.46 \%$ & & $(4.23) * * *$ \\
\hline SB & 149 & 2 & 4.90 & 1.94 & 52 & 2 & 4.27 & 1.88 & $(2.29)^{*}$ \\
\hline
\end{tabular}




\begin{tabular}{|c|c|c|c|c|c|c|c|c|c|}
\hline & & (13) & (5) & & & $(10)$ & (4) & & \\
\hline DEPDM & 149 & & $54.36 \%$ & & 52 & & $38.46 \%$ & & $(1.97)^{*}$ \\
\hline GENDIV & 149 & $\begin{array}{c}0.00 \\
(0.50)\end{array}$ & $\begin{array}{c}0.03 \\
(0.00)\end{array}$ & 0.10 & 52 & $\begin{array}{c}0.00 \\
(0.50)\end{array}$ & $\begin{array}{c}0.04 \\
(0.00)\end{array}$ & 0.12 & $(0.23)$ \\
\hline AGEDIV & 149 & $\begin{array}{c}0.82 \\
(12.87)\end{array}$ & $\begin{array}{c}5.41 \\
(5.23)\end{array}$ & 2.51 & 52 & $\begin{array}{c}0.82 \\
(13.80)\end{array}$ & $\begin{array}{c}5.89 \\
(6.40)\end{array}$ & 3.04 & $\begin{array}{l}1.01 \\
(1.29)\end{array}$ \\
\hline NATDIV & 149 & $\begin{array}{c}0.00 \\
(0.50)\end{array}$ & $\begin{array}{c}0.12 \\
(0.00)\end{array}$ & 0.19 & 52 & $\begin{array}{c}0.00 \\
(0.50)\end{array}$ & $\begin{array}{c}0.18 \\
(0.00)\end{array}$ & 0.22 & $(1.80)^{\mathrm{a}}$ \\
\hline WLAV & 149 & $\begin{array}{c}0.07 \\
(1.29)\end{array}$ & $\begin{array}{c}0.68 \\
(0.67)\end{array}$ & 0.26 & 52 & $\begin{array}{c}0.14 \\
(1.28)\end{array}$ & $\begin{array}{c}0.79 \\
(0.83)\end{array}$ & 0.27 & $\begin{array}{l}2.65^{* *} \\
(2.88)^{* *}\end{array}$ \\
\hline LNTA & 149 & $\begin{array}{c}1.41 \\
(10.93)\end{array}$ & $\begin{array}{c}5.61 \\
(5.46)\end{array}$ & 1.97 & 52 & $\begin{array}{c}1.96 \\
(9.38)\end{array}$ & $\begin{array}{c}4.67 \\
(4.32)\end{array}$ & 1.93 & $\begin{array}{c}2.95^{* *} \\
(3.12)^{* *}\end{array}$ \\
\hline CETA & 149 & $\begin{array}{c}0.02 \\
(0.92)\end{array}$ & $\begin{array}{c}0.37 \\
(0.34)\end{array}$ & 0.17 & 52 & $\begin{array}{c}0.01 \\
(0.85)\end{array}$ & $\begin{array}{c}0.33 \\
(0.30)\end{array}$ & 0.21 & $\begin{array}{l}1.09 \\
(1.60)\end{array}$ \\
\hline NITA & 149 & $\begin{array}{l}-0.11 \\
(0.31)\end{array}$ & $\begin{array}{c}0.07 \\
(0.06)\end{array}$ & 0.06 & 52 & $\begin{array}{l}-3.08 \\
(0.27)\end{array}$ & $\begin{array}{l}-0.15 \\
(-0.05)\end{array}$ & 0.50 & $\begin{array}{l}3.19^{* *} \\
(8.02)^{* * *}\end{array}$ \\
\hline CASHVV & 149 & $\begin{array}{l}-0.06 \\
(2.68) \\
\end{array}$ & $\begin{array}{c}0.24 \\
(0.17) \\
\end{array}$ & 0.29 & 52 & $\begin{array}{l}-4.68 \\
(0.73) \\
\end{array}$ & $\begin{array}{l}-0.14 \\
(0.00) \\
\end{array}$ & 0.75 & $\begin{array}{l}3.58^{* *} \\
(7.57)^{* * *}\end{array}$ \\
\hline \multicolumn{10}{|l|}{$t=-3$} \\
\hline STRUCTURED & 149 & & $62.42 \%$ & & 52 & & $38.46 \%$ & & $(4.23)^{* * *}$ \\
\hline $\mathrm{SB}$ & 149 & $\begin{array}{c}2 \\
(14)\end{array}$ & $\begin{array}{c}4.89 \\
(5)\end{array}$ & 2.01 & 52 & $\begin{array}{c}2 \\
(11)\end{array}$ & $\begin{array}{c}4.29 \\
(4)\end{array}$ & 1.82 & $(1.99)^{*}$ \\
\hline DEPDM & 149 & & $51.68 \%$ & & 52 & & $42.30 \%$ & & $(1.16)$ \\
\hline GENDIV & 149 & $\begin{array}{c}0.00 \\
(0.44)\end{array}$ & $\begin{array}{c}0.03 \\
(0.00)\end{array}$ & 0.09 & 52 & $\begin{array}{c}0.00 \\
(0.50)\end{array}$ & $\begin{array}{c}0.05 \\
(0.00)\end{array}$ & 0.14 & $(0.72)$ \\
\hline AGEDIV & 149 & $\begin{array}{c}0.82 \\
(15.33)\end{array}$ & $\begin{array}{c}5.63 \\
(5.39)\end{array}$ & 2.64 & 52 & $\begin{array}{c}0.50 \\
(13.80)\end{array}$ & $\begin{array}{c}6.32 \\
(6.82)\end{array}$ & 3.00 & $\begin{array}{l}1.58 \\
(1.99)^{*}\end{array}$ \\
\hline NATDIV & 149 & $\begin{array}{c}0.00 \\
(0.50)\end{array}$ & $\begin{array}{c}0.11 \\
(0.00)\end{array}$ & 0.19 & 52 & $\begin{array}{c}0.00 \\
(0.50)\end{array}$ & $\begin{array}{c}0.18 \\
(0.00)\end{array}$ & 0.21 & $(2.06)^{*}$ \\
\hline WLAV & 149 & $\begin{array}{c}0.07 \\
(1.29)\end{array}$ & $\begin{array}{c}0.66 \\
(0.67)\end{array}$ & 0.27 & 52 & $\begin{array}{c}0.07 \\
(1.28)\end{array}$ & $\begin{array}{c}0.78 \\
(0.80)\end{array}$ & 0.29 & $\begin{array}{l}2.57 * \\
(2.78)^{* *}\end{array}$ \\
\hline LNTA & 149 & $\begin{array}{c}1.33 \\
(10.82)\end{array}$ & $\begin{array}{c}5.42 \\
(5.38)\end{array}$ & 1.94 & 52 & $\begin{array}{c}1.05 \\
(8.82)\end{array}$ & $\begin{array}{c}4.68 \\
(4.29)\end{array}$ & 1.87 & $\begin{array}{l}2.42^{* *} \\
(2.45)^{* *}\end{array}$ \\
\hline CETA & 149 & $\begin{array}{c}0.04 \\
(0.87)\end{array}$ & $\begin{array}{c}0.37 \\
(0.36)\end{array}$ & 0.16 & 52 & $\begin{array}{c}0.04 \\
(0.93)\end{array}$ & $\begin{array}{c}0.39 \\
(0.34)\end{array}$ & 0.21 & $\begin{array}{l}0.69 \\
(0.20)\end{array}$ \\
\hline NITA & 149 & $\begin{array}{l}-0.29 \\
(0.32)\end{array}$ & $\begin{array}{c}0.07 \\
(0.06)\end{array}$ & 0.07 & 52 & $\begin{array}{l}-1.58 \\
(0.20)\end{array}$ & $\begin{array}{l}-0.01 \\
(-0.08)\end{array}$ & 0.27 & $\begin{array}{l}3.26^{* *} \\
(5.88)^{* * *}\end{array}$ \\
\hline CASHVV & 149 & $\begin{array}{l}-0.20 \\
(1.74)\end{array}$ & $\begin{array}{c}0.24 \\
(0.18)\end{array}$ & 0.23 & 52 & $\begin{array}{l}-4.80 \\
(0.54)\end{array}$ & $\begin{array}{l}-0.05 \\
(0.00)\end{array}$ & 0.76 & $\begin{array}{l}2.70^{* *} \\
(4.74)^{* * *}\end{array}$ \\
\hline
\end{tabular}

***,** and $*$ indicate statistical significance at a $0.1 \%, 1 \%$ and $5 \%$ level, respectively.

supervisory board variables:

STRUCTURED dummy variable indicating the application of the 'structure' regime to the company.

SB the number of members of the supervisory board at year-end

DEPDM dummy variable indicating the presence of one or more non-independent supervisory directors on the SB at year-end

GENDIV the Blau-indicator on the diversity in gender of the SB

AGEDIV the diversity in age of the SB measured in terms of the standard deviation

NATDIV the Blau-indicator on the diversity in nationality of the SB

WLAV the average workload of the supervisory directors on the SB in terms of full-time equivalents (FTEs)

financial control variables:

LNTA the natural logarithm of total assets (TA) in millions of euros (size measure)

CETA common equity (CE) divided by TA (leverage measure)

NITA net income (before extraordinary items; NI) divided by TA (income measure)

CASHVV cash flow (CASH) divided by TA (liquidity measure). 
As Table 1 shows, control NVs are significantly more often a 'structure $N V$ ' $(62 \%)$ than financially distressed companies $(38 \%)$. Hypothesis $\mathrm{H}_{1}$ presuming a negative relationship between the structure regime and financial distress therefore cannot be rejected.

The size of the SB differs between the samples at the 5\% level, with a median of five for the control group and four for the distressed group. Hypothesis $\mathrm{H}_{2}$ presuming a positive relationship between the number of supervisory directors and financial distress is therefore rejected. In both groups a minimum size of two is reported, which is below the legal maximum of three for the 'structure NV'. Subsection 5.2 elaborates on this issue.

SBs of control NVs have significantly more often one or more non-independents on the board on $t=-2$. Hypothesis $\mathrm{H}_{3}$ presuming a negative relationship between the presence of non-independent supervisory directors and financial distress therefore cannot be rejected.

Financially distressed companies show significantly more diverse SBs, at least with respect to nationality (on the 5\% level in $\mathrm{t}=-3$; and on the $10 \%$ level in $\mathrm{t}=-2$ ) and age (in $\mathrm{t}=-3$ on the $5 \%$ level). Hypothesis $\mathrm{H}_{4}$ presuming a negative relationship between the diversity of an SB and financial distress is rejected at least as far as it concerns diversity in nationality and age. Since only $3 \%$ of all supervisory directors in the research period were women, it could not be expected that gender diversity would turn out as a significant variable.

Concerning availability, financially distressed companies have a significantly busier SB than the control group. Hypothesis $\mathrm{H}_{5}$ presuming a positive relationship between the workload of the supervisory directors and financial distress cannot be rejected.

In short: Table 1 indicates that the SB of a financially distressed company is statistically significantly less powerful, smaller, more independent, more diverse and less available.

All financial control variables but the financial leverage measure CETA differ statistically significantly between both groups at the $1 \%$ level. The CETA exception is due to the significantly higher average leverage of the group 2 companies than that of the future bankrupt companies. The former apparently still have a buffer. Table 2 shows the correlation coefficients between the variables.

Table 2. A Spearman correlation analysis of the supervisory board related variables and financial control variables for the control sample and the financially distressed sample of listed Dutch companies from 1993 to 2003, based on panel data for $\mathrm{t}=-2$ and $\mathrm{t}=-3$ before the financial distress event in the financially distressed sample occurred

\begin{tabular}{|c|c|c|c|c|c|c|c|c|c|c|c|}
\hline & FiDi & STRUCT & SB & DEPDM & DIVGEN & DIVAGE & DIVNAT & AVWL & LNTA & CETA & NITA \\
\hline FiDi & 1 & & & & & & & & & & \\
\hline STRUCT & $-0,21^{* *}$ & 1 & & & & & & & & & \\
\hline SB & $-0,15^{* *}$ & $0,17^{* *}$ & 1 & & & & & & & & \\
\hline DEPDM & $-0,11^{*}$ & $-0,05$ & $0,26^{* *}$ & 1 & & & & & & & \\
\hline DIVGEN & 0,02 & $-0,03$ & $0,20^{* *}$ & 0,01 & 1 & & & & & & \\
\hline DIVAGE & $0,11^{*}$ & $-0,06$ & $0,20^{* *}$ & $0,16^{* *}$ & $0,11^{*}$ & 1 & & & & & \\
\hline DIVNAT & $0,14^{* *}$ & $-0,15^{* *}$ & $0,42^{* *}$ & $0,26^{* *}$ & $-0,03$ & $0,19^{* *}$ & 1 & & & & \\
\hline WLAV & $0,20^{* *}$ & $-0,06$ & $-0,11^{*}$ & 0,02 & 0,02 & 0,08 & 0,07 & 1 & & & \\
\hline LNTA & $-0,20^{* *}$ & $0,15^{* *}$ & $0,72^{* *}$ & $0,17^{* *}$ & $0,13^{* *}$ & $-0,06$ & $0,35^{* *}$ & $-0,08$ & 1 & & \\
\hline CETA & $-0,05$ & $-0,08$ & $-0,16^{* *}$ & 0,05 & $-0,02$ & 0,05 & $-0,03$ & 0,00 & $-0,34^{* *}$ & 1 & \\
\hline NITA & $-0,49^{* *}$ & 0,02 & 0,03 & 0,09 & $-0,04$ & $-0,11^{*}$ & $-0,08$ & 0,01 & 0,00 & $0,25^{* *}$ & 1 \\
\hline CASHVV & $-0,43^{* *}$ & 0,06 & $-0,05$ & 0,08 & $-0,04$ & $-0,07$ & $-0,11^{*}$ & 0,00 & $-0,12^{*}$ & $0,49^{* *}$ & $0,83^{* *}$ \\
\hline
\end{tabular}

** and * indicate statistical significance at a $1 \%$ and $5 \%$ level, respectively (two-tailed).

FiDi a dummy variable indicating financial distress.

Other variables defined below Table 1.

We added our distress variable FiDi to the table in order to show that there certainly are statistical significant relationships between financial distress and the monitoring characteristics under review, but that none has decisive power. The only rather elevated correlation coefficient $(r=0.72)$ shown in Table 2, is between the number of supervisory directors (SB) and the size of the company (LNTA). This is not alarming and multicollinearity therefore would not be an issue. 


\subsection{The Industry and Structure-NV Angle}

The results presented in Table 1 may well differ between industries and may be biased by the already long ago established structure regime. This subsection analyses the data along these characteristics.

Table 3. An analysis of the economic activity ('industry') of the control sample and the financially distressed sample of listed Dutch companies from 1993 to 2003, based on panel data for $t=-2$ before the financial distress event in the financially distressed sample occurred

\begin{tabular}{lllllllll}
\hline economic activity & manufacturing & construction & trade & transport & ICT & services & other $^{\circ}$ & total $^{\prime}$ \\
\hline control sample & 66 & 13 & 29 & 13 & 19 & 6 & 3 & 149 \\
\hline financially distressed & 17 & 0 & 6 & 1 & 21 & 5 & 2 & 52 \\
\hline as $\%$ of total sample & 41.3 & 6.5 & 17.4 & 7.0 & 19.9 & 5.5 & 2.4 & 100 \\
\hline Pearson $\chi^{2}$ & $54.51 * * *$ & & & & & & & \\
\hline Cramer's V & 0.368 & \\
$* *$ & and $*$ indicate statistical significance at a $0.1 \%, 1 \%$ and $5 \%$ level, respectively.
\end{tabular}

Column contains industries that did not meet the requirement of the test

As Table 3 shows, industry differs significantly between both samples at the $0.1 \%$ level. The IT- and services industries, represented by 51 companies in the sample of which 26 became financially distressed, show a significantly higher financial distress ratio than other industries (the 'dot.com bubble').

Table 4 analyses the data from the industry perspective (Note 30 ).

Table 4. An analysis of supervisory board related variables and financial control variables for the listed Dutch 'IT and service' industries and the other industry companies from 1993 to 2003, based on panel data for $t=-2$ and $t=-3$ before the financial distress event in the financially distressed sample occurred (significant differences only)

\begin{tabular}{|c|c|c|c|c|c|c|c|c|c|}
\hline & 'IT and s & vice' san & & & 'other in & ry' sampl & & & difference \\
\hline variable & number & $\begin{array}{c}\min \\
(\max )\end{array}$ & $\begin{array}{c}\text { mean } \\
(\text { median })\end{array}$ & $\begin{array}{c}\text { standard } \\
\text { deviation }\end{array}$ & number & $\begin{array}{c}\min \\
(\max )\end{array}$ & $\begin{array}{c}\text { mean } \\
\text { (median) }\end{array}$ & $\begin{array}{c}\text { standard } \\
\text { deviation }\end{array}$ & (|z-value $\mid)$ \\
\hline \multicolumn{10}{|l|}{$t=-2$} \\
\hline STRUCTURED & 51 & & $27 \%$ & & & & $66 \%$ & & $(4.78)^{* * *}$ \\
\hline $\mathrm{SB}$ & 51 & $\begin{array}{c}2 \\
(9)\end{array}$ & $\begin{array}{c}4.06 \\
(4)\end{array}$ & 1.59 & 150 & $\begin{array}{c}2 \\
(13)\end{array}$ & $\begin{array}{c}4.97 \\
(5)\end{array}$ & 2.00 & $(2.80)^{* *}$ \\
\hline WLAV & 51 & $\begin{array}{c}0.14 \\
(1.19)\end{array}$ & $\begin{array}{c}0.79 \\
(0.78)\end{array}$ & 0.27 & 150 & $\begin{array}{c}0.07 \\
(1.29)\end{array}$ & $\begin{array}{c}0.69 \\
(0.68)\end{array}$ & 0.26 & $(2.37)^{*}$ \\
\hline LNTA & 51 & $\begin{array}{c}1.96 \\
(10.88)\end{array}$ & $\begin{array}{c}4.86 \\
(4.42)\end{array}$ & 2.09 & 150 & $\begin{array}{c}1.41 \\
(10.93)\end{array}$ & $\begin{array}{c}5.53 \\
(5.34)\end{array}$ & 1.94 & $(2.31)^{*}$ \\
\hline DISTRESSED & 51 & & $51 \%$ & & 150 & & $17 \%$ & & $(4.73)^{* * *}$ \\
\hline$t=-3$ & & & & & & & & & \\
\hline STRUCTURED & 51 & & $27 \%$ & & & & $66 \%$ & & $(4.78)^{* * *}$ \\
\hline SB & 51 & $\begin{array}{c}2 \\
(8)\end{array}$ & $\begin{array}{l}3.90 \\
(4)\end{array}$ & 1.46 & 150 & $\begin{array}{c}2 \\
(14)\end{array}$ & $\begin{array}{l}5.02 \\
(5)\end{array}$ & 2.05 & $(3.52)^{* * *}$ \\
\hline WLAV & 51 & $\begin{array}{c}0.07 \\
(1.21)\end{array}$ & $\begin{array}{c}0.78 \\
(0.78)\end{array}$ & 0.29 & 150 & $\begin{array}{c}0.07 \\
(1.29)\end{array}$ & $\begin{array}{c}0.66 \\
(0.67)\end{array}$ & 0.27 & $(2.81)^{* *}$ \\
\hline LNTA & 51 & $\begin{array}{c}1.06 \\
(9.80)\end{array}$ & $\begin{array}{c}4.69 \\
(4.27)\end{array}$ & 2.01 & 150 & $\begin{array}{c}1.33 \\
(10.82)\end{array}$ & $\begin{array}{c}5.42 \\
(5.37)\end{array}$ & 1.89 & $(2.49)^{*}$ \\
\hline DISTRESSED & 51 & & $51 \%$ & & 150 & & $17 \%$ & & $(4.73)^{* * *}$ \\
\hline
\end{tabular}

The table divides the data after IT- and services related companies, and companies in other industries. The sample of IT- and services companies contains smaller companies that have smaller SBs and that are less often structured (27\% as opposed to $66 \%$ for the control sample). The average workload of the SB is higher, as was the company's chance on financial distress. The latter is three times as large (51\%) for a IT- or service company than for a control company (17\%). In short: the SB of an IT- and services related company is statistically significantly less powerful, smaller and less available.

Since the structure regime exists from 1971 and the way supervisory directors are appointed differed in the period of research largely between an ordinary NV, namely by the general meeting, and a 'structure NV', namely by the SB 
itself, the results presented in section 5.1 may be biased. Therefore, Table 5 shows an analysis of the data from a 'structure- $N V$ ' perspective (Note 31 ).

Table 5. An analysis of supervisory board related variables and financial control variables for the listed Dutch 'ordinary NV' and the 'structure NV' companies from 1993 to 2003, based on panel data for $t=-2$ and $t=-3$ before the financial distress event in the financially distressed sample occurred (significant differences only)

\begin{tabular}{|c|c|c|c|c|c|c|c|c|c|}
\hline & \multicolumn{4}{|c|}{ 'ordinary NV' sample } & \multicolumn{4}{|c|}{ 'structured NV' sample } & \multirow{2}{*}{$\begin{array}{l}\text { difference } \\
\text { (|z-value })\end{array}$} \\
\hline variable & number & $\begin{array}{c}\min \\
(\max )\end{array}$ & $\begin{array}{c}\text { mean } \\
\text { (median) }\end{array}$ & $\begin{array}{c}\text { standard } \\
\text { deviation }\end{array}$ & number & $\begin{array}{c}\min \\
(\max )\end{array}$ & $\begin{array}{c}\text { mean } \\
\text { (median) }\end{array}$ & $\begin{array}{c}\text { standard } \\
\text { deviation }\end{array}$ & \\
\hline \multicolumn{10}{|l|}{$t=-2$} \\
\hline SB & 88 & $\begin{array}{c}2 \\
(11)\end{array}$ & $\begin{array}{c}4.43 \\
(4)\end{array}$ & 1.99 & 113 & $\begin{array}{c}2 \\
(13)\end{array}$ & $\begin{array}{l}4.97 \\
(5)\end{array}$ & 1.87 & $(2.42)^{*}$ \\
\hline NATDIV & 88 & $\begin{array}{c}0.00 \\
(0.50)\end{array}$ & $\begin{array}{c}0.16 \\
(0.00)\end{array}$ & 0.21 & 113 & $\begin{array}{c}0.00 \\
(0.50)\end{array}$ & $\begin{array}{c}0.12 \\
(0.00)\end{array}$ & 0.18 & $(1.68)^{\mathrm{a}}$ \\
\hline LNTA & 88 & $\begin{array}{c}1.41 \\
(10.93)\end{array}$ & $\begin{array}{c}5.15 \\
(4.46)\end{array}$ & 2.35 & 113 & $\begin{array}{c}2.40 \\
(10.88)\end{array}$ & $\begin{array}{c}5.37 \\
(5.35)\end{array}$ & 1.66 & $(2.12)^{*}$ \\
\hline DISTRESSED & 88 & & $36 \%$ & & 113 & & $18 \%$ & & $(2.99)^{* *}$ \\
\hline \multicolumn{10}{|l|}{$t=-3$} \\
\hline SB & 88 & $\begin{array}{c}2 \\
(10)\end{array}$ & $\begin{array}{c}4.41 \\
(4)\end{array}$ & 1.93 & 113 & $\begin{array}{c}2 \\
(14)\end{array}$ & $\begin{array}{c}4.99 \\
(5)\end{array}$ & 1.98 & $(2.57)^{*}$ \\
\hline NATDIV & 88 & $\begin{array}{c}0.00 \\
(0.50)\end{array}$ & $\begin{array}{c}0.17 \\
(0.00)\end{array}$ & 0.21 & 113 & $\begin{array}{c}0.00 \\
(0.50)\end{array}$ & $\begin{array}{c}0.10 \\
(0.00)\end{array}$ & 0.17 & $(2.54)^{*}$ \\
\hline LNTA & 88 & $\begin{array}{c}1.06 \\
(10.82)\end{array}$ & $\begin{array}{c}4.99 \\
(4.47)\end{array}$ & 2.29 & 113 & $\begin{array}{c}2.46 \\
(9.80)\end{array}$ & $\begin{array}{c}5.43 \\
(5.38)\end{array}$ & 1.62 & $(2.14)^{*}$ \\
\hline DISTRESSED & 88 & & $36 \%$ & & 113 & & $18 \%$ & & $(2.99)^{* *}$ \\
\hline
\end{tabular}

Since a number of large companies are exempt from the structure regime, it is to be expected that the difference in number (SB) and size (LNTA) is smaller than for the financially distressed and control companies in Table 1. However, the difference is still statistically significant. The same goes, but only at the $10 \%$ level for $\mathrm{t}=-2$, for diversity in nationality. Moreover, Table 5 reveals that $36 \%$ of the ordinary NVs come to face financial distress, while this is only $18 \%$ for the 'structure-NVs'. In short: a structure NV is statistically significantly larger than an ordinary NV, its SB is larger and less diverse.

One of the measurable effects of the structure regime is that it requires a minimum number of three supervisory directors. Table 6 analyses the difference between companies with less than three supervisory directors as opposed to companies with more than three supervisory directors.

Table 6. An analysis of supervisory board related variables and financial control variables for listed Dutch NVs with less than three NEDs and other listed NVs from 1993 to 2003, based on panel data for $\mathrm{t}=-2$ and $\mathrm{t}=-3$ before the financial distress event in the financially distressed sample occurred (significant differences only)

\begin{tabular}{|c|c|c|c|c|c|c|c|c|c|}
\hline & \multicolumn{4}{|c|}{ 'less than three NEDs' sample } & \multicolumn{4}{|c|}{ 'three or more NEDs' sample } & \multirow[t]{2}{*}{ difference } \\
\hline variable & number & $\begin{array}{c}\min \\
(\max )\end{array}$ & $\begin{array}{c}\text { mean } \\
\text { (median) }\end{array}$ & $\begin{array}{c}\text { standard } \\
\text { deviation }\end{array}$ & number & $\begin{array}{c}\min \\
(\max )\end{array}$ & $\begin{array}{c}\text { mean } \\
\text { (median) }\end{array}$ & $\begin{array}{l}\text { standard } \\
\text { deviation }\end{array}$ & \\
\hline \multicolumn{10}{|l|}{$t=-2$} \\
\hline DEPDM & 15 & & $27 \%$ & & 186 & & $52 \%$ & & \\
\hline \multirow[t]{2}{*}{ AGEDIV } & 15 & 1.00 & 3.60 & 2.29 & 186 & 0.82 & 5.69 & 2.63 & $(2.94)^{* *}$ \\
\hline & & $(9.00)$ & $(3.50)$ & & & $(13.80)$ & $(5.67)$ & & \\
\hline \multirow[t]{2}{*}{ LNTA } & 15 & 2.24 & 3.88 & 1.50 & 186 & 1.41 & 5.48 & 1.99 & $(3.25)^{* *}$ \\
\hline & & $(8.10)$ & $(3.67)$ & & & $(10.93)$ & $(5.31)$ & & \\
\hline DISTRESSED & & & $47 \%$ & & & & $24 \%$ & & $(1.91)^{\mathrm{a}}$ \\
\hline \multicolumn{10}{|l|}{$t=-3$} \\
\hline \multirow[t]{2}{*}{ NATDIV } & 14 & 0.00 & 0.04 & 0.13 & 187 & 0.00 & 0.14 & 0.20 & $(1.93)^{\mathrm{a}}$ \\
\hline & & $(0.50)$ & $(0.00)$ & & & $(0.50)$ & $(0.00)$ & & \\
\hline \multirow[t]{2}{*}{ AGEDIV } & 14 & 0.50 & 4.00 & 2.99 & 187 & 0.82 & 5.94 & 2.69 & $(2.59)^{* *}$ \\
\hline & & (10.50) & $(3.50)$ & & & (15.33) & (5.89) & & \\
\hline \multirow[t]{2}{*}{ LNTA } & 14 & 1.06 & 3.54 & 1.06 & 187 & 1.33 & 5.36 & 1.94 & $(3.66)^{* * *}$ \\
\hline & & $(5.37)$ & $(3.50)$ & & & (10.82) & $(5.26)$ & & \\
\hline
\end{tabular}


Companies with less than three supervisory directors are smaller (LNTA) and their SBs are more often 100\% independent and show lower age diversity. Moreover, Table 6 reveals for $t=-2$ that $47 \%$ of the 'small supervisory board-NVs' come to face financial distress, while this is only $24 \%$ for the 'three or more supervisory board-NVs' (at the $10 \%$ level). Admittedly, the number of small supervisory board NVs is only 15 . Still, the difference in the chance on financial distress is striking.

\section{A Confrontation between the Results and the Law}

This chapter confronts the results of section 5 with the legal and regulatory provisions on power, number, dependence, diversity and workload of supervisory directors and NEDs.

Evidently, the structure regime established in the law in 1971 is a success from a financial distress viewpoint. Companies under the structure regime suffer statistically significantly less financial distress at the $0.1 \%$ level. A $36 \%$ of ordinary NVs was financially distressed in the period of research and only $18 \%$ of the 'structure-NVs' (Table 5). The difference in distress incidence can be explained by four factors for a 'structure NV': (a) the legal regime itself, (b) a higher number of supervisory directors, (c) less nationality diversity, and (d) the bigger size of the company (Table 5). The SB of both company groups did not differ in other aspects.

Although there is no reason to suppose that these results do not hold at present, it must be admitted that the number of 'structure-NVs' has been decreased since the early 2000s, due to international expansion and thus the possibility of exemption on the one hand, and shareholder reluctance to maintain the structure regime voluntarily on the other hand. Whether the shift of powers in 2004 from the SB to the shareholders on the adoption of the annual accounts and the appointment of supervisory directors had any influence on the effectiveness of the SB in the structure regime, has not been researched yet. Our results confirm the earlier results of Van Ees, Postma et al. (2003) that the 'structure NV' does not show better 'positive' performance than ordinary NVs: a significant relationship between income- or cashflow variables and the regime could not be established.

Part of the introduction of the structure regime, was a mandatory provision that the SB should consist of at least three people. Table 6 shows that only 7\% of the listed companies had an SB of less than three. The provision apparently has become accepted for both types of NVs.

Tables 1, 5 and 6 clearly show that the implementation of the structure regime in the law is a success from a financial distress point of view.

In the research period there were no provisions on independence, diversity and availability. Presently there are. Based on the results of our statistical analysis we will estimate the effects of these provisions from a financial distress point of view.

The DCGC already in its 2003 version provides for a maximum of one non-independent supervisory director on the board. However, our results do not show that independence is an invaluable asset for a supervisory director in times of near financial distress. On the contrary, it may very well be an asset for the SB to have one or more non-independent supervisory directors (Table 1). Although our results do not directly oppose the DCGC provision, which accepts one non-independent NED on the board, we feel that the present attitude to reject non-independence by principle should be scrutinized. Instead, there seems to be every reason to relieve this strong Dutch standard of 'one only', and to consider the British and US standards, requiring a majority of directors to be independent.

The DCGC defines diversity not only in terms of gender, but explicitly mentions age as well. As discussed, our results bear no importance on the gender diversity. As for age diversity, Table 1 shows a higher diversity in the financially distressed sample. Nationality diversity is significantly higher for distressed companies as well. The implications from a financial distress perspective are twofold: (a) there is no indication at all that diversity in age or nationality is positively associated with control sample companies; and (b) on the contrary, age and nationality diversity are higher in the financially distressed group implying there is every reason to rethink the impact of diversity.

Finally, the DCGC and the law apparently did well to address the workload issue. Busy directors and financial distress are statistically significantly positively related. However, there is neither supporting evidence for the desirability of the number of five non-executive directorships for large companies that the law prescribes as a maximum, nor for the exclusion of associations under the regime; or for the inclusion of large BVs and stichtingen (foundations) for that matter. Anyone will understand that a supervisory position on Royal Philips Electronics NV requires more time, than that on the around 1500 times smaller NV Koninklijke Delftsch Aardewerkfabriek "De Porceleyne Fles Anno 1653". For the law however, they count equal. This makes a waste of supervisory talent. We 
advise the government to commission research on the time consumption of supervisors on the different categories of institutions, in order to improve this legislation accordingly.

\section{Conclusion}

From an economic point of view, the implementation of the structure regime seems an overwhelming success. Recent legislation on the availability of supervisors seems also well targeted - but may need some fine tuning.

However, no economic justification could be discovered for provisions on dependence and diversity. Our results suggest that these provisions have opposite effects: 'independence' and 'diversity' are predominant in the financially distressed companies.

The results are embedded in the specific Dutch two-tier system and studies companies in times of near financial distress. However, the results may very well be valuable for the one-tier system as well. A statutory or article-based powerful board, with well available supervisory directors/NEDs, that is statistically significantly what counts when it comes to handling serious financial difficulties of the company. Independence and diversity of the supervisors is not found to play a significant role in that situation.

The limitations to this study are threefold. Firstly, the data relates to the period before the 2004 legislative changes and the entry into force of the DCGC. Ever since, the composition of the SB has been changed and as a consequence the monitoring characteristics of the SB. Secondly, the number of female supervisory directors was low, around 3\% over the period, making the impact of gender diversity hard to test. In the meantime this percentage has increased to largely over $10 \%$. Thirdly, the question whether the establishment of a SB makes a difference, could not be researched since all companies had one.

We would recommend further study on the relevance of the various monitoring characteristics of supervisory directors and NEDs in times of financial distress on a European scale. We were able to do our research on Dutch data largely due to the 'dotcom bubble'. Generally the number of bankrupt listed companies pro country is too low to do research on this 'downward performance'.

\section{Acknowledgement}

The authors would like to thank prof.dr. Jan Adriaanse (Leiden Law School), dr. Dick van Offeren (Leiden Law School) and dr. Niels van Zijl (at the time: Erasmus School of Law) for their valuable comments on a previous version of this paper.

\section{References}

Adams, R. B., \& D. Ferreira. (2009). Women in the Boardroom and Their Impact on Governance and Performance. Journal of financial economics, 94(2), 291-309. http://dx.doi.org/10.1016/j.jfineco.2008.10.007

Albert, M. (1993). Capitalism against Capitalism. London, Whurr Publishers.

Andres, P. d., et al. (2005). Corporate boards in OECD countries: size, composition, functioning and effectiveness. Corporate governance, 13(2), 197-210. http://dx.doi.org/10.1111/j.1467-8683.2005.00418.x

Argenti, J. (1976). Corporate collapse: the causes and symptoms. London, McGrawHill.

Argenti, J. (1986A, February). Predicting corporate failure. Accountancy, 97, 157-158.

Argenti, J. (1986B, July). Spot danger signs before it's too late. Accountancy, 98, 101-102.

Baker, M., \& P. A. Gompers. (2003, October). The determinants of board structure at the initial public offering. Journal of law and economics, XLVI. http://dx.doi.org/10.1086/380409

Becht, M., et al. (2005). Corporate governance and control. ECGI working paper series in finance. ECGI: Working Paper 02/2002, updated August 2005, 2001-2122.

Beiner, S., et al. (2004). Is board size an independent corporate governance mechanism? Kyklos 57(3), 327-356. http://dx.doi.org/10.1111/j.0023-5962.2004.00257.x

Bhagat, S., \& B. Black. (2002). The non-correlation between board independence and long-term firm performance. Journal of Corporation Law, 27(2), 231-273.

Bhagat, S., \& B. Bolton. (2008). Corporate governance and firm performance. Journal of corporate finance, 14(3), 257-273. http://dx.doi.org/10.1016/j.jcorpfin.2008.03.006

Blair, M. (1995). Ownership and control: rethinking corporate governance for the twenty-first century. In T. Clarke (Ed.), Theories of Corporate Governance (pp. 174-188). London and New York, Routledge. 
Calkoen, W. J. L. (2011). The One-Tier Board. ESL. Rotterdam, EUR: 495.

Carter, D. A., et al. (2010). The Gender and Ethnic Diversity of US Boards and Board Committees and Firm Financial Performance. Corporate governance: an international review 18(5), 396-414. http://dx.doi.org/10.1111/j.1467-8683.2010.00809.x

Carter, D. A., et al. (2003). Corporate governance, board diversity, and firm value. Financial Review, 38, 33-53. http://dx.doi.org/10.1111/1540-6288.00034

Daily, C. M., \& D. R. Dalton. (1994). Bankruptcy and corporate governance: the impact of board composition and structure. Academy of Management Journal, 37(6), 1603-1617. http://dx.doi.org/10.2307/256801

Dalton, D. R., et al. (1998). Meta-analytic reviews of board composition, leadership structure, and financial

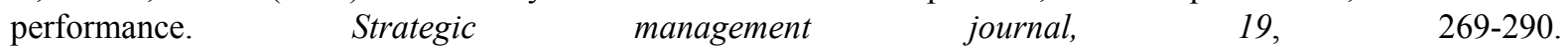
http://dx.doi.org/10.1002/(SICI)1097-0266(199803)19:3<269::AID-SMJ950>3.0.CO;2-K

Duchina, R., et al. (2010). When are outside directors effective? Journal of financial economics, 96(2), 195-241. http://dx.doi.org/10.1016/j.jfineco.2009.12.004

Ees, H. v., et al. (2003). Board characteristics and corporate performance in the Netherlands. Eastern Economic Journal, 29(1), 41-58.

Fama, E. F., \& M. C. Jensen. (1983, June). Separation of ownership and control. Journal of law and economics, 26, 301-325. http://dx.doi.org/10.1086/467037

Farrell, K. A., \& P. L. Hersch. (2005). Additions to corporate boards: the effect of gender. Journal of corporate finance, 11, 85-106. http://dx.doi.org/10.1016/j.jcorpfin.2003.12.001

Francoeur, C., et al. (2007). Gender diversity in corporate governance and top management. Journal of business ethics.

Goodridge, M. (2007, February). Competing expectations of the NED. Governance, 2007(160).

Hambrick, D. C. (1987). The top management team: key to strategic success. California management review, 30(1), 88-108. http://dx.doi.org/10.2307/41165268

Harris, I. C., \& K. Shimizu. (2004). Too busy to serve? An examination of the influence of overboarded directors. Journal of management studies, 41(5), 775-798. http://dx.doi.org/10.1111/j.1467-6486.2004.00453.x

Hermalin, B. E., \& M. S. Weisbach. (1988). The determinants of board composition. The Rand Journal of Economics, 19(4), 589-606. http://dx.doi.org/10.2307/2555459

Higgs, D. (2003). Review of the role and effectiveness of non-executive directors. London, The Department of Trade and Industry.

Hill, N. T., et al. (1996). Evaluating firms in financial distress: an event history analysis. Journal of applied business research, 12(3), 60-71.

Hillman, A. J., \& T. Dalziel. (2003). Boards of directors and firm performance: integrating agency and resource dependence perspectives. Academy of management review, 28(3), 383-396. http://dx.doi.org/10.2307/30040728

Jensen, M. C. (1993). The modern industrial revolution, exit, and the failure of internal control systems. The journal of finance, 48(3), 831-880. http://dx.doi.org/10.1111/j.1540-6261.1993.tb04022.x

Jensen, M. C., \& W. H. Meckling. (1976). Theory of the firm: managerial behavior, agency costs and ownership structure. Journal of financial economics, 3(4), 305-360. http://dx.doi.org/10.1016/0304-405X(76)90026-X

Jong, A. d., et al. (2005). The role of self-regulation in corporate governance: evidence and implications from The Netherlands. Journal of corporate finance, 11(3), 473-503. http://dx.doi.org/10.1016/j.jcorpfin.2004.01.002

Keough, D. R. (2008). The ten commandments for business failure. London, Penguin.

Kiel, G. C., \& G. J. Nicholson. (2006). Multiple directorships and corporate performance in Australian listed companies. Corporate governance, 14(6), 530-546. http://dx.doi.org/10.1111/j.1467-8683.2006.00528.x

Klein, A. (1998, April). Firm performance and board committee structure. Journal of law and economics, XLI. http://dx.doi.org/10.1086/467391

Lipton, M., \& J. W. Lorsch. (1992). A modest proposal for improved corporate governance. Business lawyer, 48(1), 59-77. 
Mashayekhi, B., \& M. S. Bazaz. (2008). Corporate governance and firm performance in Iran. Journal of Contemporary Accounting \& Economics, 4(2), 156-172. http://dx.doi.org/10.1016/S1815-5669(10)70033-3

Mertens, G. M. H., \& N. Knop. (2010). The impact of ownership and board structure on CEO compensation in the Netherlands. SSRN, Erasmus University, Rotterdam School of Management.

O'Connell, V., \& N. Cramer. (2010). The relationship between firm performance and board characteristics in Ireland. European Management Journal. http://dx.doi.org/10.1016/j.emj.2009.11.002

Ohlson, J. A. (1980). Financial ratios and the probabilistic prediction of bankruptcy. Journal of accounting research, 18(1), 109-131. http://dx.doi.org/10.2307/2490395

Pelled, L. H. (1996). Demographic diversity, conflict, and work group outcomes: an intervening process theory. Organization science, 7(6), 615-631. http://dx.doi.org/10.1287/orsc.7.6.615

Pfeffer, J., \& G. R. Salancik. (1978). The external control of organizations: a resource dependency perspective. New York, Harper \& Row.

Pompe, P. P. M., \& J. Bilderbeek. (2000). Prestaties van modellen en ratio's bij het voorspellen van modellen. MAB oktober: 465-472.

Pugliese, A., et al. (2009). Boards of directors' contribution to strategy: a literature review and research agenda. Corporate governance: an international review, 17(3), 292-306. http://dx.doi.org/10.1111/j.1467-8683.2009.00740.x

Romano, R., et al. (2008). The promise and peril of corporate governance indices. Columbia law review, 108(8), 1803-1882.

Ruigrok, W., et al. (2007). Nationality and gender diversity on Swiss Corporate Boards. Corporate governance, 15(4), 546-557. http://dx.doi.org/10.1111/j.1467-8683.2007.00587.x

Santen, B. P. A. (2011). On the role of monitoring near financial distress - an economic and legal analysis. Erasmus School of Law. Rotterdam, EUR. dr.: 424. http://repub.eur.nl/pub/22676/

Skeel, D. A. (2005). Icarus in the boardroom. New York, Oxford University Press.

Smit, J. (2008). De Prooi, Amsterdam, Prometheus.

Van Veen, K., \& J. Elbertsen. (2008). Governance regimes and national diversity in corporate boards: a comparative study of Germany, the Netherlands and the United Kingdom. Corporate governance: an international review, 16(5), 386-399. http://dx.doi.org/10.1111/j.1467-8683.2008.00698.x

Winter, J., \& C. Cools. (2008). Loon naar werken. Het Financieele Dagblad 12 September 2008.

Yermack, D. (1996). Higher market valuation of companies with a small board of directors. Journal of financial economics, 40, 185-211. http://dx.doi.org/10.1016/0304-405X(95)00844-5

Zahra, S. A., \& J. A. Pearce. (1989). Boards of directors and corporate financial performance: a review and integrative model. Journal of management, 15(2), 291-334. http://dx.doi.org/10.1177/014920638901500208

Zijl, N. J. M. V. (2012). The Importance of Board Independence - A Multidisciplinary Approach. Deventer, Kluwer.

Zmijewski, M. E. (1984). Methodological issues related to the estimation of financial distress prediction models. Journal of accounting research, 22(supplement), 59-82. http://dx.doi.org/10.2307/2490859

\section{Notes}

Note 1. s 2:153 Dutch Civil Code (DCC).

Note 2. Total exemption: s 2:153(3) DCC; partial exemption: 2:155; 2:155a DCC.

Note 3. Only for the full, mandatory regime.

Note 4. s 2:164a(4) DCC (new) requires for the one-tier structure the approval of the majority of the NEDs.

Note 5. s 111(4) Aktiengesetz (AktG), second sentence.

Note 6. s 111(4) AktG, first sentence. For the Netherlands: HR 21 January 1955, NJ 1959, 43 (Forum-bank).

Note 7. HR 13-07-2007, JOR 2007, 178 (Bank of America/ABNAMRO and VEB) r.o. 4.3. This is in accordance with principle II.1 of the Dutch Corporate Governance Code (DCGC). In best practice II.1.2b however, the DCGC requires SB approval of the strategy. 
Note 8 . In this paper called the 'executive board'.

Note 9. s 95 AktG; s 7 Gesetz über die Mitbestimmung der Arbeitnehmer (Mitbestimmungs-gesetz - MitbestG).

Note 10. s 2:158 (2) DCC.

Note 11. LR 9.8.6(5) and (6) require a listed company to make a statement of how it has applied the Main principles of the UKCGC as well as to whether the company has complied to the other relevant provisions of the UKCGC. The UKCGC does not address the 'number issue' directly, but requirements on mainly independence of directors in e.g. B.1.2, C.3.1. and D.2.1. influence the number.

Note 12. NYSE Listed Company Manual, 303A.01.

Note 13. The Dutch s 2:161 DCC forbids a supervisory directorship on a 'structure NV' for people employed by the company, a subsidiary or a trade-union, involved in the determination of labour conditions on the company. The German s 100 AktG forbids a supervisory directorship for legal representatives of a subsidiary as well as cross-directorships.

Note 14. s 2:391(5) DCC and the 'Besluit van 23 december 2004' (Staatsblad 2004, 747) as changed by 'Besluit van 10 december 2009' (Staatsblad 2009, 545). The explicit mention in the DCC to a corporate governance code dates from 2008

Note 15. This is the definition of DCGC III.2.2. Although the DCGC did not apply in the research period, the definition facilitates an objective distinction between the NEDs.

Note 16. Through the declaration of conformity pursuant to s 161 AktG as amended by the Transparency and Disclosure Law, entered into force on July 26, 2002, the Code has a legal basis.

Note 17. s 2:158(3) DCC.

Note 18. Principle III.3 DCGC: The supervisory board shall aim for a diverse composition in terms of such factors as gender and age. Best practice provisions III.3.1: The supervisory board shall prepare a profile of its size and composition, taking account of the nature of the business, its activities and the desired expertise and background of the supervisory board members. The profile shall deal with the aspects of diversity in the composition of the supervisory board that are relevant to the company and shall state what specific objective is pursued by the board in relation to diversity. In Germany, best practice 5.4.1. reads: The Supervisory Board shall specify concrete objectives regarding its composition which, whilst considering the specifics of the enterprise, take into account the international activities of the enterprise, potential conflicts of interest, the number of independent Supervisory Board members (..) and diversity. These concrete objectives shall, in particular, stipulate an appropriate degree of female representation. In the UK, Supporting Principle B.2. reads: The search for board candidates should be conducted, and appointments made, on merit, against objective criteria and with due regard for the benefits of diversity on the board, including gender. Idem: code provision B.2.4. and on evaluation supporting principle B.6.

Note 19. s 2:166 DCC (new). However, KPN N.V., a listed Dutch telecom provider, announced recently that it has stopped 'positive discrimination' of women in general, since other groups e.g. the employees from non-Dutch origin felt discriminated (NRC, 26 September 2014).

Note 20. s 2:142a DCC (new). A company is large if it fits the following criteria:

\begin{tabular}{|l|l|l|l|}
\hline company & small (2:396 DCC) & medium (2:397 DCC) & large (2:394 DCC) \\
\hline $\begin{array}{l}\text { total assets (2:396 (1.a)) } \\
\text { DCC }\end{array}$ & $\leq € 4,4$ million & $>€ 4,4$ and $\leq € 17,5$ & $>€ 17,5$ million \\
\hline $\begin{array}{l}\text { net turnover }(2: 377(6)) \\
\text { DCC }\end{array}$ & $\leq € 8,8$ million & $>€ 8,8$ and $\leq € 35$ & $>€ 35$ million \\
\hline employees (average) & $<50$ & $<250$ & $\geq 250$ \\
\hline
\end{tabular}

A company is 'small' or 'medium' if two out of three of the criteria apply on two successive balance sheet dates (s 2:396(1), 2:397(1); for new companies s 2:398(1) DCC). The disclosure criteria are given in s 2:396 for 'small' and $\mathrm{s}$ 2:397 DCC for 'medium' companies. This system applies to the NV, BV, coöperatie; and to a vereniging or a stichting maintaining an enterprise with a two-year consecutive annual turnover of at least 4,4 Mio (s 2:360(3) DCC) unless the vereniging or stichting is already obliged by another specific law to adequate disclosure. 
Note 21. So did Mashayekhi, B. and M. S. Bazaz (2008). "Corporate governance and firm performance in Iran." Journal of Contemporary Accounting \& Economics 4(2): 156-172.; Pugliese, A., et al. (2009). "Boards of directors' contribution to strategy: a literature review and research agenda." Corporate governance: an international review 17(3): 292-306; O'Connell, V. and N. Cramer (2010). "The relationship between firm performance and board characteristics in Ireland." European Management Journal.

Note 22. To which can be added: decision-making; see Beiner, Drobretz et al (2004: 354).

Note 23. Dalton, Daily et al. (1998) in their meta-analysis find no relationship. Mashayekhi and Bazaz (2008) report for Iran that the presence of outside directors strengthens the firms' performance. O'Connell and Cramer (2010) find a significant association between firm performance and the percentage of NEDs on the board.

Note 24. The first is said to be the case with Chairman Martinez of ABN AMRO Bank (Smit, J. (2008), De Prooi, Amsterdam, Prometheus; ; the latter with the Chairman of the Audit Committee Fahlin in the AHOLD case (pleitnota 13 April 2006, mr J. Sjöcrona, available on the internet).

Note 25 . Measured by being quoted at year-end.

Note 26. Moreover, Zmijewski, M. E. (1984) argues that the resulting bias 'does not appear to affect the statistical inferences or overall classification rates.'

Note 27. More precisely: the Handelsregister which is kept by the Chamber of Commerce.

Note 28. Wet Melding Zeggenschap, a former Dutch law, at present part of the Wet op het financieel toezicht (Wft), that required shareholders passing certain thresholds, like 5\%, to register this with the Netherlands Authority for the Financial Markets (AFM).

Note 29. A Dutch guide for data on directors. Taken as close as possible to the year the data were needed for.

Note 30. It reports for the variables mentioned in Table 1 the significant results at the $5 \%$ level only.

Note 31 . It reports for the variables mentioned in Table 1 the significant results at the $5 \%$ level only. 